\title{
Overview on the Convergence of US GAAP into IFRS in Saudi Arabia
}

\author{
Malik R. Elhaj \\ Department of Accounting \& Finance, Prince Mohammad Bin Fahd University (PMU), Kingdom of Saudi Arabia
}

Received October 29, 2019; Revised November 25, 2019; Accepted December 4, 2019

Copyright $\mathrm{C} 2019$ by authors, all rights reserved. Authors agree that this article remains permanently open access under the terms of the Creative Commons Attribution License 4.0 International License

\begin{abstract}
The purpose of this study is to explore the convergence mechanism and process of SME's financial statements into the International Financial Reporting Standards(IFRS) including the benefits and the impact of financial reporting on users of financial statements. The paper also explains the early IFRS adoption in Saudi Arabia according to the guideline provided by Saudi Organizations for Certified Public Accountants (SOCPA). The mechanism of the convergence incudes: nature of information to gather during the convergence, the significant IFRS to include in the financial reports, and financial accounts affected by the convergence. The article results find that the fair value adoption and Zakat rules are the most challenges for SME's in the financial stamens convergence process in addition to lack of adequate guidance by SOCPA and the complexity of IFRS. The Zakat rules need more interpretation and transparency. Therefore, companies spend more effort in financial statements convergence for Zakat purpose. In addition, more collaboration and training are required to improve the quality of financial reporting which would reduce the time consumption and convergence costs including cost of outsourcing (offshoring) financial statements convergence into IFRS.
\end{abstract}

Keywords Convergence, Financial Reporting, IFRS, SME's, US GAAP

\section{Introduction}

Amidst the diversity of international accounting standards, this paper contributes to existing literature by further exploring the convergence mechanism and process of Saudi Arabian SME's financial statements into the International Financial Reporting Standards (IFRS). It is crucial for industry TO strive for reliable, accurate and transparent information to enhance ultimate dissemination of business financial information for all concerned stakeholders. The purpose of this study is to focus on the strategy for convergence, the sequential procedures to follow, collation of data, and the prioritizing of standards to be adopted. The impetus of this topic is to add further clarity and understanding of the progress made by early IFRS adoption in Saudi Arabia according to the guideline provided by Saudi Organizations for Certified Public Accountants (SOCPA).

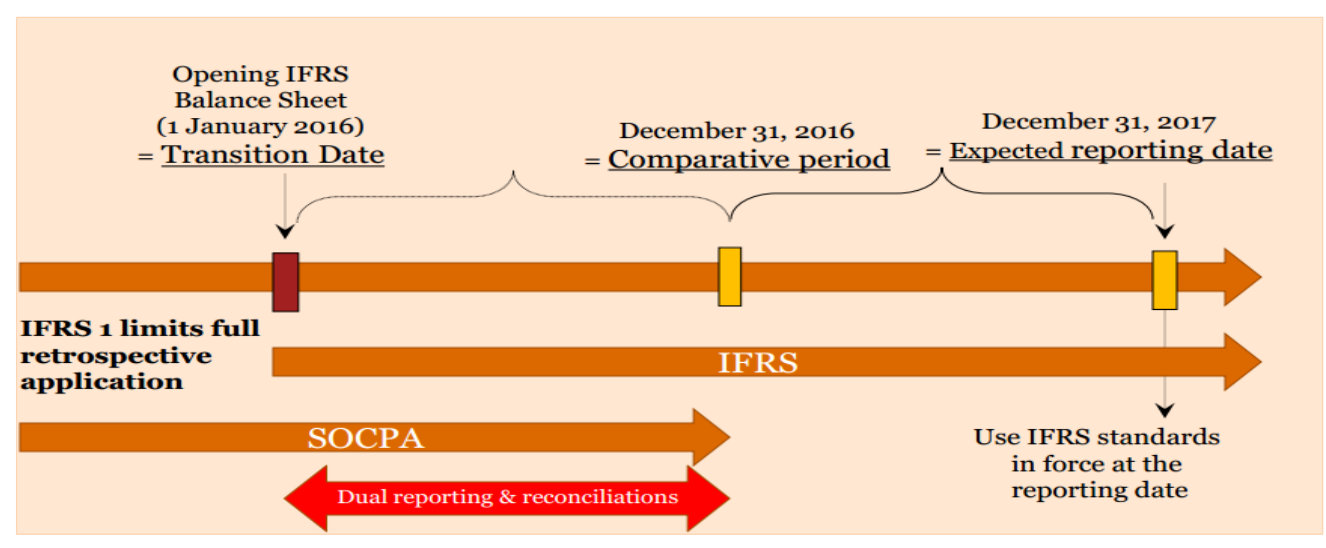

Reference: www.socpa.org.sa

Figure 1. Illustration of timeline convergence adopted by SOCPA 
The following section provides a literature review. Section three explains the required information for convergence. Section four outlines the significant changes in IFRS. Discussion and recommendations in section five highlights the harmonization issues between agents. The final section provides concluding observations.

The convergence into IFRS was first adopted by Saudi Arabia is in 2017 by public companies and from 2018 for SMEs. This was considered a challenge in term of cost of adoption, need for training, complexity of IFRS, and lack of adequate implementation guidance. (Deloitte, 2016).

The Figure 1 illustrates the time line of the convergence in Saudi Arabia including the opening, comparative, and expected reporting date.

\section{Literature Review}

Although the IFRS standards have been adopted by 144 jurisdictions. For all or most companies among 166 jurisdictions. 86 jurisdictions require or permit the use of IFRS for SME's. US is one of the major economies has yet to agree to adopt IFRS; instead, it kept its own standards (Zeff 1999). Saudi Arabia join countries in the world using IFRS.to have a positive impact to Saudi financial system (Manduca, 2016). SOCPA approved an IFRS convergence plan called "SOCPA project for transition to international accounting and auditing standard" (Manduca, 2016). The below figure 2 (Figure 2), shows the convergence approach in Saudi Arabia

\section{Convergence Approach}

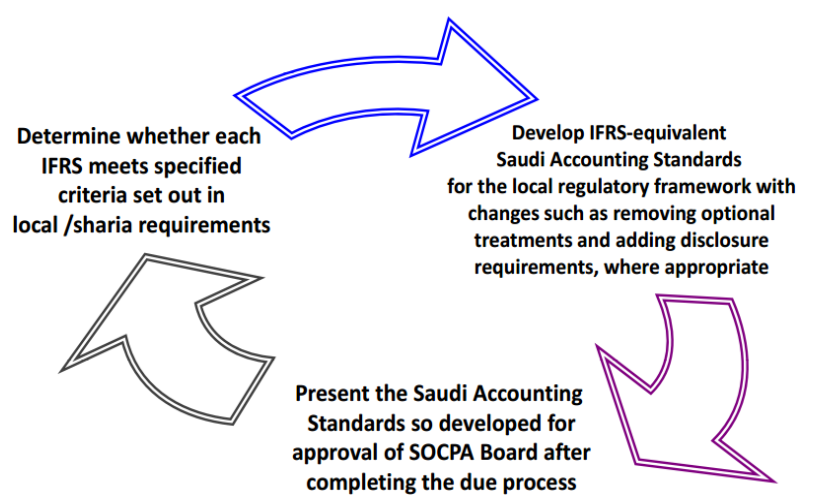

Reference: www.socpa.org.sa

Figure 2. Illustration of the Convergence Approach Adopted by SOCPA

The Saudi Arabian authorities have made a directive orders that all the SMEs should implement the system. As a result, the IFRS comes with various impacts in the small and medium enterprise some changes will have positive impact and others will be negative (Steel \& Sagga, 2015). Figure 3 below illustrate the convergence project and its impact on business, people, system, and financial reporting.

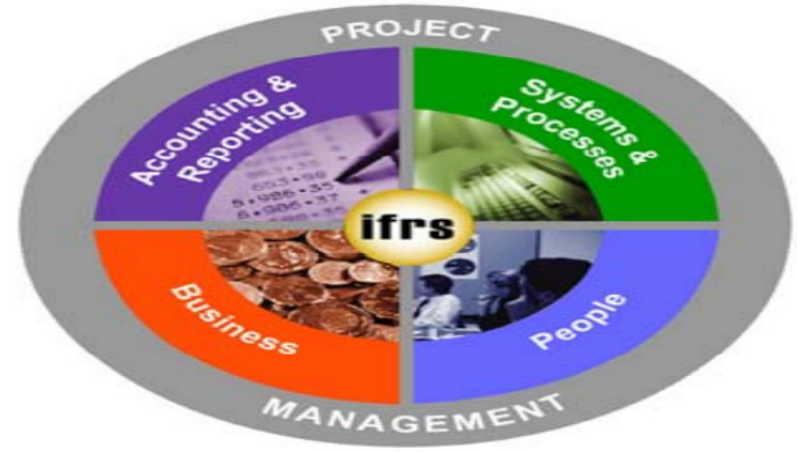

Reference: www.socpa.org.sa

Figure 3. Illustration of IFRS Impact

This paper addresses how the system affects the SME's financial reporting based on the perception of the implementation. Every firm aims to provide a high-quality financial report. The IFRS system is a crucial system in the business industry and system will provides reliable, accurate and transparent information, and it eases the work (Steel \& Sagga, 2015). Additionally, the use of the same system in the business industry enhances the comparability of the results between various firms (Laique, 2017).

IFRS will affect many parts of financial reports. IFRS seeks to provide high standard to introduce greater consistency to financial reports inside the used countries to be internationally recognized. Figure 4 illustrate the overall impact of IFRS on financial reporting.

Several authors have noted lack of consistency in the application of IFRS often results in reported income being overstated (Street and Gary, 2002; Prather-Kinsey and Meek, 2004). The main benefits may arise from the adoption of IFRS including: access to capital; enhancing cross-border listings; providing better investment opportunities; increasing transparency; comparability (Jermakowicz and Gornik-Tomaszewski, 2006); and the opportunity to review existing policies ( $\mathrm{PwC} 2006$ ). On the other hand, the major criticisms of IFRS has been that it will bring much more volatility into the income statement thus making it more difficult to judge a company's performance (Jermakowicz and Gornik-Tomaszewski, 2006; KPMG, 2007). The complexity of the standards and the corresponding lack of guidance are challenge to the adoption (Larson and Street, 2004; Ernst \& Young, 2006; (Jermakowicz and Gornik-Tomaszewski, 2006; PwC, 2006; Fearnley et al., 2007; ICAS 2007) 


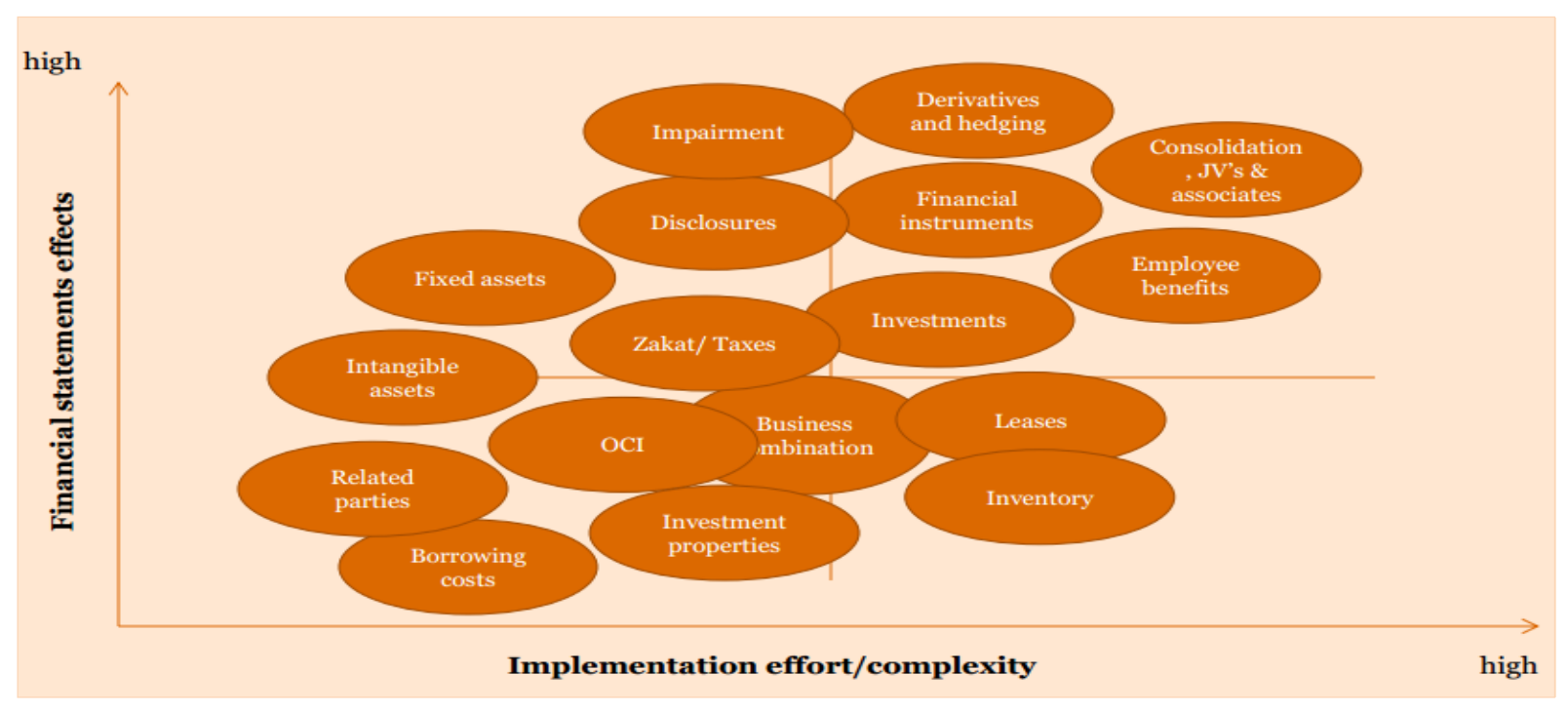

Reference: www.socpa.org.sa

Figure 4. Illustration of the effect of IFRS on Financial Statement Reporting

Crystal Ayres (2017) have been looking at this and classified pros and cons of IFRS into the following: the advantages of having IFRS accounting system are many in the deferent levels. As we mentioned before, IFRS will affect in the most four different aspects. Which are administrative and accounting changes, financial statement and periodic reporting, accounting for assets and inventory and revenue recognition. However, the advantages are something different. Its effects in general way no matter what the aspect is. Adopting IFRS will give many beneficial results which are related comparability financial reports and more flexibility using philosophy that based on principles not rules and this will result more flexibility. The disadvantages of adopting the IFRS are the cost of convergence including the needs to hire new professional stuff and training cost.

David Ingram (2019) form Chron have classified the changes of IFRS into four major changes. The four main aspect that will be affected by IFRS are administrative and accounting changes, financial statement and periodic reporting, accounting for assets and inventory and revenue recognition. The Administrative and Accounting Changes Complying with IFRS standards requires a number of significant changes in the way that accounting departments collect classify and present financial data. Financial Statements and Periodic Reporting IFRS recognize the same set of standard financial statements, including the income statement, balance sheet and statement of cash flows. For example, businesses must specify the nature of expenses listed in income statements, in addition to the functional category, either by organizing expenses according to nature or disclosing their nature in the attached notes. Accounting for Assets and Inventory IFRS presents a few major changes that can affect the way a US business presents its assets and inventory. For example: The last-in, first-out method of inventory costing is prohibited under IFRS. Also, another example is accounting for asset depreciation can require changes, as well, since under IFRS a business must account for the depreciation of components separate from depreciation of equipment as a whole under certain circumstances.

Revenue Recognition Principles IFRS defines revenue as a gross inflow of economic benefit resulting in an increase in equity accounts. The differences in revenue recognition can impact net income and a wide range of financial ratios, leading to large changes in a company's performance measures when switching to IFRS. This can require a company to alter its business model, pricing structures or payment terms to preserve existing ratio valuations.

\section{Required Information as Part of the Convergence}

The below Table is showing list of required items as part of the convergence process. The accountant can present them as worksheet table include the client response (if the convergence is done by external party) or part of internal worksheet if the company will do the convergence internally. 
Table 1. Convergence Accountant Worksheet

\begin{tabular}{|c|c|c|}
\hline Line Item & Requirement/Clarification & Response/ Comment \\
\hline Nature of Business & $\begin{array}{l}\text { Nature of business like source of raw water, channel/mode of distribution, use of } \\
\text { any brand name etc. }\end{array}$ & \\
\hline $\begin{array}{l}\text { Foreign currency exposure } \\
\text { risk }\end{array}$ & $\begin{array}{l}\text { As per IFRS } 7 \text {, company is required to provide the exposure to foreign exchange } \\
\text { risk, policies of the company to mitigate such risk along with sensitivity analysis } \\
\text { of the same. For this purpose, you need the exposure amount to foreign currency } \\
\text { at year end } 20 \times 22^{* *} \text { and } 20 \times 1^{*} \text {. }\end{array}$ & \\
\hline Accounting Policies & Accounting policies adopted in preparation of financial statement $20 \mathrm{x} 1$ & \\
\hline Employees Debtors & $\begin{array}{l}\text { Any separate contract is made while granting advances to employees? If yes, it } \\
\text { is good to have copy of } 1-2 \text { contracts. If no, then elaborate terms and conditions } \\
\text { agreed upon between employer and employee for advances to employees. (Also } \\
\text { you need the ledger of employee loans from Jan } 20 x 1 \text { till date to understand the } \\
\text { repayment pattern) }\end{array}$ & \\
\hline Property, plant \& equipment & $\begin{array}{l}\text { For fixed assets, IFRS } 1 \text { provides the optional exemption of using transition date } \\
\text { fair value as deemed cost. In case if company does not avail this choice then the } \\
\text { IFRS } 16 \text { needs to be applied. The company has the choice whether to opt. for the } \\
\text { exemption available under IFRS } 1 \text { or not? }\end{array}$ & \\
\hline Leasing arrangement & Any asset taken on lease? If yes, get more details on lease agreement. & \\
\hline Revenue & $\begin{array}{l}\text { For understanding the IFRS impact on revenue, get sample of each type of } \\
\text { revenue contracts with customer (including PO). If written contracts are not } \\
\text { there \& arrangements are on verbal basis, then get details of verbal terms and } \\
\text { conditions decided by the company along with the payment terms for our } \\
\text { diagnostic purpose. }\end{array}$ & \\
\hline $\begin{array}{l}\text { Allowance for Employee's } \\
\text { end of service benefits }\end{array}$ & $\begin{array}{l}\text { More details about end of service benefits of the company for which this } \\
\text { provision is made. How the amounts are determined? Whether any actuarial } \\
\text { valuation is carried out or not? If yes then you need actuarial reports. }\end{array}$ & \\
\hline $\begin{array}{l}\text { Ledger wise Trial Balance } \\
\text { for the year } 20 \times 2\end{array}$ & $\begin{array}{l}\text { Trial Balance as per books to understand ledgers and its grouping.(Containing } \\
\text { ledger wise opening balance, transactions \& closing balance) }\end{array}$ & \\
\hline $\begin{array}{c}\text { Contingent } \\
\text { Assets/Contingent Liabilities }\end{array}$ & $\begin{array}{l}\text { Are there any financial arrangements like financial or performance guarantees } \\
\text { with third party or associate concerns? }\end{array}$ & \\
\hline Related Party transactions & $\begin{array}{l}\text { Any transaction with related party? If yes, details with transaction amounts and } \\
\text { closing balance on both balance sheet dates i.e. } 20 \times 1 \text { and } 20 \times 2 \text { are required. }\end{array}$ & \\
\hline All Ledger transaction report & $\begin{array}{l}\text { All transaction report of } 20 \times 2 \text { will help to prepare financial statements as per } \\
\text { IFRS for the year ending } 20 \times 2 \text {. }\end{array}$ & \\
\hline Trade Receivables & $\begin{array}{l}\text { Customer wise ageing analysis of the trade receivables of } 20 \times 1 \text { and } 20 \times 2 \text { for } \\
\text { preparation of Expected credit loss model for provisioning on trade receivables } \\
\text { as per simplified approach allowed by IFRS 9. (This will also help in elaborating } \\
\text { note on credit risk.) }\end{array}$ & \\
\hline Vacation benefit & Elaborate on vacation benefit. Is it paid within next 12 months? & \\
\hline
\end{tabular}

$20 \mathrm{x} 1$ is previous financial year

$20 \times 2$ is Current financial year

Note Format and content of this worksheet can vary.

\section{Significant Changes in IFRS}

\subsection{Adoption of Fair Value Hierarchy}

\subsubsection{The Following Are the Fair Value Hierarchy Levels}

Level 1: Level 1 hierarchy includes financial instruments measured using quoted prices. This includes listed equity instruments, traded bonds and mutual funds that have quoted price. The fair value of all equity instruments (including bonds) which are traded in the stock exchanges is valued using the closing price as at the reporting period. The mutual funds are valued using the closing NAV.

Level 2: The fair value of financial instruments that are not traded in an active market (for example, traded bonds, over-the counter derivatives) is determined using valuation techniques which maximize the use of observable market data and rely as little as possible on entity-specific estimates. If all significant inputs required to fair value an instrument are observable, the instrument is included in

Level 3: If one or more of the significant inputs is not based on observable market data, the instrument is included in level 3.

\subsubsection{Fair Value of Financial Assets and Liabilities Measured at Amortized Cost}

The carrying amounts of trade receivables, cash and cash equivalents, financial liabilities are considered to be the same as their fair values, due to their short-term nature.

\subsection{First-time Adoption of IFRS}

Financial statements for the year ended 31 December, 2018 in Saudi Arabia are the first financial statements 
company has prepared in accordance with IFRS. For periods up to and including the year ended 31 December 2017, the company prepared its financial statements in accordance with the SOCPA GAAP.

Since these are the first financial statements, where IFRS has been adopted, the company is required to comply with the requirements of IFRS 1, first time Adoption of International Financial Reporting Standards. As per IFRS 1, the financial statements are required to be prepared and presented as if the IFRS was adopted for all the periods presented. In preparing its opening IFRS statement of Financial Position, the company has analyzed the impact and adjusted and reclassified certain balances that were previously reported under SOCPA GAAP.

\subsection{IFRS Mandatory Exceptions}

\section{a) Estimates}

An entity's estimates in accordance with IFRS at the date of adoption of IFRS shall be consistent with the estimates made for the same date in accordance with the previous GAAP (after adjustments to reflect any difference in accounting policies), unless there is objective evidence that those estimates were in error. IFRS estimates as at January 1, 2017 are consistent with the estimates as at the same date made in conformity with the previous GAAP.

b) De-recognition of financial assets and liabilities

IFRS 1 requires a first-time adopter to apply the de-recognition provisions of IFRS 9 prospectively for transactions occurring on or after the date of transition to IFRS. However, IFRS 1 allows a first-time adopter to apply the de-recognition requirements in IFRS 9 retrospectively from a date of the entity's choosing, provided that the information needed to apply IFRS 9 to financial assets and financial liabilities derecognised as a result of past transactions was obtained at the time of initially accounting for those transactions.

The Company has elected to apply the de-recognition provisions of IFRS prospectively from the date of transition to IFRS.

\section{c) Classification and measurement of financial assets}

IFRS 1 requires an entity to assess classification and measurement of financial assets on the basis of the facts and circumstances that exist at the date of transition to IFRS. In addition, the entity presents assets and liabilities in the balance sheet based on current/non-current classification.

An asset is treated as current when it is:

(1) Expected to be realized or intended to be sold or consumed in the normal operating cycle.

(2) Held primarily for the purpose of trading.

(3) Expected to be realized within twelve months after the reporting period, or
(4) Cash and cash equivalents unless restricted from being exchanged or used to settle a liability for at least twelve months after the reporting period.

All other assets are classified as non-current.

A liability is current when:

(1) It is expected to be settled in the normal operating cycle.

(2) It is held primarily for the purpose of trading.

(3) It is due to be settled within twelve months after the reporting period, or

(4) There is no unconditional right to defer the settlement of the liability for at least twelve months after the reporting period.

\subsection{Leases}

IFRS 16 will affect primarily the accounting by lessees and will result in the recognition of almost all leases on balance sheet. The standard removes the current distinction between operating and financing leases and requires recognition of an asset (the right to use the leased item) and a financial liability to pay rentals for virtually all lease contracts. An optional exemption exists for short-term and low-value leases.

\subsection{Foreign Currency Transactions and Translations}

\section{(a) Functional and presentation currency}

Items included in financial statements are measured using the currency of 'the primary economic environment in which the entity operates ("functional currency"). The financial statements are presented in Saudi Riyals (SAR), which is the entity's functional and presentation currency.

\section{(b) Transactions and balances}

Foreign currency transactions are translated into the functional currency using exchange rates at the date of the transaction. Foreign exchange gains and losses resulting from the settlement of such transactions and from the translation of monetary assets and liabilities denominated in foreign currencies at year end exchange rates are generally recognized in profit or loss.

Foreign exchange gains and losses that relate to borrowings are presented in the statement of profit or loss, within finance costs. All other foreign exchange gains and losses are presented in the statement of profit or loss on a net basis within other gains/(losses).

Non-monetary items that are measured at fair value in a foreign currency are translated using the exchange rates at the date when the fair value was determined. Non-monetary assets and liabilities that are measured based on historical cost in a foreign currency are translated at the exchange rate at the date of the transaction. 


\subsection{Revenue Recognition}

Revenue is measured at the fair value of the consideration received or receivable. Amounts disclosed as revenue are net of returns, trade allowances, rebates, and amounts collected on behalf of third parties. The company recognizes revenue when the amount of revenue can be reliably measured, it is probable that future economic benefits will flow to the entity and specific criteria have been met.

\subsection{Zakat}

"In accordance with the regulations of the General Authority of Zakat and Tax ("GAZT"), the Company is subject to zakat attributable to the Saudi shareholder and to income taxes attributable to the foreign shareholder. Provisions for zakat is charged to the equity accounts of the Saudi and the foreign shareholders, respectively. Additional amounts payable, if any, at the finalization of final assessments are accounted for when such amounts are determined.

\subsection{Deferred Tax}

Deferred tax is provided using the balance sheet liability method on temporary differences between the tax bases of assets and liabilities and their carrying amounts for financial reporting purposes at the reporting date. Deferred tax assets are recognized to the extent that it is probable that future taxable income will be available against which the deductible temporary differences, unused tax losses, depreciation carry-forwards and unused tax credits could be utilized.

Deferred tax assets and liabilities are measured based on the tax rates that are expected to apply in the period when the asset is realized or the liability is settled, based on tax rates and tax laws that have been enacted or substantively enacted by the balance sheet date. The carrying amount of deferred tax assets is reviewed at each reporting date and adjusted to reflect changes in probability that sufficient taxable profits will be available to allow all or part of the asset to be recovered.

Deferred income tax assets and liabilities are off-set against each other and the resultant net amount is presented in the balance sheet, if and only when, (a) the company has a legally enforceable right to set-off the current income tax assets and liabilities, and (b) the deferred income tax assets and liabilities relate to income tax levied by the same taxation authority. Deferred tax is recognized in the Statement of Profit and Loss except to the extent it relates to items recognized directly in equity or other comprehensive income, in which case it is recognized in equity or other comprehensive income.

\subsection{Cash and Cash Equivalents}

For the purpose of presentation in the statement of cash flows, cash and cash equivalents includes cash on hand, deposits held at call with financial institutions, other short-term, highly liquid investments with original maturities of three months or less that are readily convertible to known amounts of cash and which are subject to an insignificant risk of changes in value.

\subsection{Trade Receivables}

Trade receivables are recognized initially at fair value and subsequently measured at amortized cost, less provision for impairment if any.

\subsection{Financial Assets}

The classification depends on the entity's business model for managing the financial assets and the contractual terms of the cash flows. The Initial recognition and measurement of financial assets is on trade-date, the date on which the Company commits to purchase or sell the asset. Financial assets are derecognized when the rights to receive cash flows from the financial assets have expired or have been transferred and the Company has transferred substantially all the risks and rewards of ownership. At initial recognition, the Company measures a financial asset at its fair value plus, in the case of a financial asset not at fair value through profit or loss, transaction costs that are directly attributable to the acquisition of the financial asset. Transaction costs of financial assets carried at fair value through profit or loss are expensed in statement of profit or loss.

Subsequent measurement is at amortized cost, financial assets that are held within a business model whose objective is to hold financial assets in order to collect contractual cash flows that are solely payments of principal and interest, are subsequently measured at amortized cost using the Effective Interest Rate (EIR) method less impairment, if any. The amortization of EIR and loss arising from impairment, if any is recognized in the Statement of Profit and Loss.

Financial assets that are held within a business model whose objective is achieved by both, selling financial assets and collecting contractual cash flows that are solely payments of principal and interest, are subsequently measured at fair value through other comprehensive income. Fair value movements are recognized in the other comprehensive income (OCI). Interest income measured using the EIR method, foreign exchange gains and losses and impairment losses, if any are recognized in the Statement of Profit and Loss. On derecognition, cumulative gain or loss is previously recognized in OCI is never reclassified from the equity to 'other income' in the Statement of Profit and Loss (according to IFRS 9, the change in fair value are measured through OCI at deregonition).

A financial asset not classified as either amortized cost or Fair Value at Other Comprehensive Income (FVOCI), is 
classified as Fair Value at Profit or Loss (FVTPL). Such financial assets are measured at fair value with all changes in fair value, including interest income and dividend income if any, recognized as 'other income' in the Statement of Profit and Loss.

Impairment of financial assets is related for trade receivables only, the company can apply the simplified approach permitted by IFRS 9 Financial Instruments, which requires expected lifetime losses to be recognized from initial recognition of the receivables. The company derecognizes a financial asset when the contractual rights to the cash flows from the financial asset expire, or it transfers the contractual rights to receive the cash flows from the asset. In the scope of IFRS, there is always an impairment of financial assets if the asset is not measured at fair value through profit and loss. The impairment is in the Stage 1 at the level of 12-month ECL (Expected Credit Loss) and in the Stage 2 at the Level of Lifetime ECL.

\subsection{Financial Liabilities}

Financial liabilities are recognized when the company becomes a party to the contractual provisions of the instrument. Financial liabilities are initially measured at its fair value plus or minus, in the case of a financial liability not at fair value through profit or loss, transaction costs that are directly attributable to the issue of the financial liability. The company measures all its financial liabilities as subsequently measured at amortized cost using the EIR method, except for financial guarantee contracts. Financial guarantee contracts are subsequently measured at the higher of:

(1) the amount determined in accordance with the expected credit loss model under IFRS 9 Financial Instruments and

(2) the amount initially recognized less, where appropriate, the cumulative amount of income recognized in accordance with the principles of IFRS 15 Revenue from contracts with customers.

Financial liabilities carried at fair value through profit or loss is measured at fair value with all changes in fair value recognized in the Statement of Profit and Loss. Derecognition

A financial liability is derecognised when the obligation specified in the contract is discharged, cancelled or expires.

\subsection{Offsetting Financial Instruments}

Financial assets and liabilities are offset and the net amount is reported in the balance sheet where there is a legally enforceable right to offset the recognized amounts and there is an intention to settle on a net basis or realize the asset and settle the liability simultaneously. The legally enforceable right must not be contingent on future events and must be enforceable in the normal course of business and in the event of default, insolvency or bankruptcy of the
Company or the counterparty.

\subsection{Property, Plant and Equipment}

Property, plant and equipment are stated at historical cost less depreciation. Historical cost includes expenditure that is directly attributable to the acquisition of the items.

Subsequent costs are included in the asset's carrying amount or recognized as a separate asset, as appropriate, only when it is probable that future economic benefits associated with the item will flow to the company and the cost of the item can be measured reliably. The carrying amount of any component accounted for as a separate asset is derecognised when replaced. All other repairs and maintenance are charged to profit or loss during the reporting period in which they are incurred. For the assets added during the financial year under review, depreciation is charged on pro-rata basis from the date of commissioning.

The assets residual values and useful lives are reviewed, and adjusted if appropriate at the end of each reporting period. An asset's carrying amount is written down immediately to its recoverable amount if the asset's carrying amount is greater than its estimated recoverable amount. Gains and losses on disposals are determined by comparing proceeds with carrying amount. These are included in profit or loss within other gains/(losses).

Property, plant and equipment should be tested for impairment at the end of each reporting period, the Company reviews the carrying amounts of its property, plant and equipment to determine whether there is any indication that those assets have suffered an impairment loss. If any such indication exists, the recoverable amount of the asset is estimated in order to determine the extent of the impairment loss (if any). If the recoverable amount of an asset is estimated to be less than its carrying amount, the carrying amount of the asset is reduced to its recoverable amount. An impairment loss is recognized immediately in the Statement of Profit and Loss. When an impairment loss subsequently reverses, the carrying amount of the asset is increased to the revised estimate of its recoverable amount, but so that the increased carrying amount does not exceed the carrying amount that would have been determined had no impairment loss been recognized for the asset in prior years. A reversal of an impairment loss is recognized immediately in the Statement of Profit and Loss.

\subsection{Trade and Other Payables}

These amounts represent liabilities for goods and services provided to the company prior to the end of financial year which are unpaid. Trade and other payables are presented as current liabilities unless payment is not due within 12 months after the reporting period. They are recognized initially at their fair value and subsequently measured at amortized cost using the effective interest method.

(a) Borrowings 
Borrowings are initially recognized at fair value, net of transaction costs incurred. Borrowings are subsequently measured at amortized cost. Any difference between the proceeds (net of transaction costs) and the redemption amount is recognized in profit or loss over the period of the borrowings using the effective interest method.

\section{(b) Borrowings costs}

General and specific borrowing costs that are directly attributable to the acquisition, construction or production of a qualifying asset are capitalized during the period of time that is required to complete and prepare the asset for its intended use or sale. Qualifying assets are assets that necessarily take a substantial period of time to get ready for their intended use or sale. Investment income earned on the temporary investment of specific borrowings pending their expenditure on qualifying assets is deducted from the borrowing costs eligible for capitalization.

\subsection{Provisions and Contingencies}

Provisions are recognized when the company has a present legal or constructive obligation as a result of past events, it is probable that an outflow of resources will be required to settle the obligation and the amount can be reliably estimated. Provisions are not recognized for future operating losses.

Provisions are measured at the present value of management's best estimate of the expenditure required to settle the present obligation at the end of the reporting period. The discount rate used to determine the present value is a pre-tax rate that reflects current market assessments of the time value of money and the risks specific to the liability. The increase in the provision due to the passage of time is recognized as interest expense.

Present obligations arising under onerous contracts are recognized and measured as provisions. An onerous contract is considered to exist where the Company has a contract under which the unavoidable costs of meeting the obligations under the contract exceed the economic benefits expected to be received from the contract. A disclosure for a contingent liability is made when there is a possible obligation or a present obligation that may, but probably will not require an outflow of resources embodying economic benefits or the amount of such obligation cannot be measured reliably. When there is a possible obligation or a present obligation in respect of which likelihood of outflow of resources embodying economic benefits is remote, no provision or disclosure is made.

Contingent asset is a possible asset that arises from past events and whose existence will be confirmed only by the occurrence or non-occurrence of one or more uncertain future events not wholly within the control of the entity. Contingent assets are not recognized but disclosed only when an inflow of economic benefits is probable.

\subsection{Employees Benefits}

The Company provides end of service benefits to its employees in accordance with the requirements of the Saudi Arabia Labor and Workmen Law. The company has availed option given to SME's to adopt simplification in end of service benefit calculations instead of appointing independent actuary for the valuation purpose.

\subsection{Critical Estimates and Judgements}

The preparation of financial statements requires the use of accounting estimates which, by definition, will seldom equal the actual results. This note provides an overview of the areas that involved a higher degree of judgement or complexity, and of items which are more likely to be materially adjusted due to estimates and assumptions turning out to be different than those originally assessed. Estimates and judgements are continually evaluated. They are based on historical experience and other factors, including expectations of future events that may have a financial impact on the company and that are believed to be reasonable under the circumstances. The areas involving critical estimates or judgements are:

\section{(a) Estimated useful life of property, plant \& equipment.}

The company reviews the estimated useful lives of property, plant and equipment at the end of each reporting period. There was no change in the useful life of property, plant and equipment as compared to previous year.

(b) Impairment of trade receivables.

The impairment provisions for trade receivables are based on the estimates made by the management.

\section{(c) Employees end of benefit plan.}

The Company provides end of service benefits to its employees in accordance with the requirements of the Saudi Arabia Labor and Workmen Law. Company has availed the option given to SME to adopt simplification in end of service benefit calculations instead of appointing independent actuary for the valuation purpose.

\section{Discussion}

Organizations in Saudi Arabia are confronting a time of progress in their bookkeeping rehearses because of changes being actualized by the Saudi Organization of Certified Public Accountants (SOCPA). SOCPA has supported International Financial Reporting Standards (IFRSs) with certain alterations bringing about extra revelations and guaranteeing consistence with Shariah. SOCPA required every recorded organization to apply embraced IFRSs from 2017 through unlisted organizations will receive from 2018. The change to IFRS guarantees straightforward, tantamount 
and reliable monetary data to control speculators in settling on ideal venture choices. A portion of the key advantages that the organizations will appreciate from IFRS appropriation include: expanded remote direct venture (FDI), improved quality detailing, equivalence, and more straightforwardness to perform chance evaluations on budget summaries and different proportions. Further, IFRS consistence is certifiably not a onetime exercise. Organizations ought to hold or contract the vital assets to guarantee smooth and consistent consistence of IFRS. This join setting up consultative gatherings to be available to respond rapidly to difficulties went up against and preparing and improvement of their workers." Beginning from 2018, all elements which are not recorded are required to embrace IFRS with a choice to apply IFRS for little and medium endeavors (SME's), (Reda, 2019).

\section{Conclusions and Recommendations}

The convergence has many challenges for small enterprise in Saudi Arabia. The challenges that will face this era will be in three main areas financial, knowledge and experience. This will be a big challenge for many businesses inside Saudi Arabia. SOCPA approved an IFRS convergence plan called "SOCPA project for transition to international accounting and auditing standard". So, on the basis of that, the IFRS comes with various impacts in the small and medium enterprise some changes will have positive impact and other will be negative (Steel \& Sagga, 2015). Every firm should also aim to provide a high-quality financial report. The IFRS system is a crucial system in the business industry and system will provides reliable, accurate and transparent information, and it eases the work (Steel \& Sagga, 2015). IFRS will improve the financial reporting in Saudi Arabia. It will support 2030 vision. It also will help the companies to globalize their businesses.

SOCPA needs to consider more interpretation for the IFRS including adequate guidelines, training plan with collaboration with management, accountant, and organizational entities to improve the quality of financial reporting, would reduce the time consumption and convergence costs particularly if the company relies on outsourcing (offshoring) the financial statements convergence.

\section{REFERENCES}

[1] Ball, R. (2006). "International Financial Reporting Standards (IFRS): pros and cons for investors", Accounting and business research, 36, 5-27.

[2] Barth, M. E., Landsman, W. R., \& Lang, M. H. (2008). International Accounting Standards and accounting quality,
Journal of accounting research, 46(3), 467-498.

[3] Dean, K. (2015). "Doing Business in the Kingdom of Saudi Arabia". Retrieved from https://www.pwc.com/m1/en/tax/do cuments/doing-business-guides/doing-business-guide-ksa.pdf

[4] Deloitte (2016). "Adoption of IFRS in Saudi Arabia". Retrieved from: https://2.deloitte.com/xe/en/pages/about-delo itte/articles/on-malta/adoption-of-IFRS-in- sa.html.

[5] Denzin, N. \& Lincoln, Y. (1998). "The landscape of qualitative research: Theories and Issues", London: Sage.

[6] Ernst \&Young (2017). "IFRS adoption in Kingdom of Saudi Arabia

[7] Ernst \&Young (2006). "IFRS: Observation on the implementation of IFRS”, Sept., E\&Y, London, 30.

[8] Fearnley, S. Gillies, A. Hines, T and Willett, C. (2007). "Bewildered but better informed: A qualitative interview based study into the attitudes of some UK accountants and regulators to the EU IFRS conversion project prior to its implementation in the UK", London, ICAEW, 103.

[9] Godfrey, J., Hodgson, A., Tarca, A., Hamilton, J., \& Holmes, S. (2010). "Accounting theory", 7th ed, Wiley

[10] Hung, M., \& Subramanyam, K. R. (2007). "Financial statement effects of adopting international accounting standards: the case of Germany". Review of accounting studies, 12(4), 623-657.

[11] Inigram, D. (2019). "How IFRS Will Affect Businesses?" Retrieved from: https://smallbusiness.chron.com/ifrs-affect-b usinesses-81857.html

[12] Institute of Chartered Accountants of Scotland (2007). "Principles into practice: Key points from the too late for principles?" Conference held in October 2006, February, Edinburgh, ICAS, 19.

[13] Jeanjean, T., \& Stolowy, H. (2008). "Do accounting standards matter? An exploratory analysis of earnings management before and after IFRS adoption", Journal of Accounting and Public Policy, 27(6), 480-494.

[14] Jermakowicz, E., Gornik-Tomaszewski, S. (2006). "Implementation IFRS from the perspective of EU publicly traded companies", Journal of International Accounting, Auditing and Taxation, 15,170- 196.

[15] Larson, R. and Street, D. (2004). "Convergence with IFRS in an expanding Europe: progress and Obstacles identified by Large Accounting firms' survey", Journal of International Accounting, Auditing and Taxation, 13, 89-119.

[16] KPMG (2007). International Financial Reporting Standards: The quest for a global language, London, KPMG, 460.

[17] Prather-Kinsey, J. and Meek, G. (2004). "The effect of revised IAS 14 on segment reporting by IAS companies", European Accounting Review, 13(2), 213-234.

[18] PriceWaterhouseCooper (2005). “The investors' view”, November, London, PWC, 27. 
[19] PiceWaterhouseCooper (2006). "IFRS: Embracing Change", July, London, PWC, 8.

[20] Street, D. (2002). "An interview with Sir David Tweedie", Journal of International Financial Management and Accounting, 15, 109-126.

[21] Yin, Robert K. (2014). "Case study research: Design and methods", Los Angeles, CA: Sage.

[22] Zeff, S. (1999). The coming confrontation on international accounting standards, Irish Accounting Review, 5(2), 89-117. 